УДК $550.36(045)$

Н.І. Бахова, к.ф.-м.н., доц.

\title{
ТЕПЛОВА МОДЕЛЬ ЧОРНОМОРСЬКОЇ ЗАПАДИНИ
}

Національний авіаційній університет

E-mail: bakhova_nataly@mail.ru

Побудовано двовимірну теплову модель Чорноморської западини на основі методу скінченних елементів. Розроблено методику отримання детального розподілу температур $i$ теплових потоків. Розглянуто вплив рельєфу, контрастної теплопровідності, нерівномірної теплогенерації, перемінних граничних умов на структуру теплового поля. Отримано високоточний розподіл температур і теплових потоків. Точність рішення у разі застосування лінійної апроксимації базисної функиї становить не більше 0,6\%.

The two-dimensional thermal model of Black Sea hollow on the basis of a finite elements method is constructed. The reception technique of detailed distribution of temperatures and heat flows is developed. A relief influence on thermal field structure, contrast heat conductivity, non-uniform radiogenic heat generation and variable boundary conditions is considered. High-precision distribution of temperatures and heat flows is received. The decision accuracy at linear approximation use of basic function makes no more than 0,6\%.

Построена двухмерная тепловая модель Черноморской впадины на основе метода конечных элементов. Разработана методика получения детального распределения температур и тепловых потоков. Рассмотрено влияние рельефа, контрастной теплопроводности, неравномерной радиогенной генерации тепла, переменных граничных условий на структуру меплового поля. Получено высокоточное распределение температур и тепловых потоков. Точность решения при использовании линейной аппроксимации базисной функиии составляет не более $0,6 \%$.

\section{Вступ}

Тепловий потік $є$ основним і достовірним джерелом інформації про глибинні температури, фазовий стан земних надр і природу рушійних сил тектогенезу.

Аналіз експериментальних даних щодо розподілу теплового потоку на поверхні Землі надає інформацію про енергетику геодинамічних процесів та теплофізичну структуру середовища.

Дані детальних розрахунків щодо приповерхневого теплового режиму необхідні для класифікації геотермічних аномалій за фізико-математичним принципом, побудови комплексної системи інтерпретації геологогеофізичних даних та прогнозу глибинних температур.

(C) Н.І. Бахова, 2011
Методи інтерпретації збурень теплового поля розроблені менше, ніж інших геофізичних полів з огляду на те, що у формуванні геотермічних аномалій задіяно значно більше природних факторів.

Спостережений тепловий потік вважається поверхневим, але він вимірюється на дискретних глибинах. Якщо середовище неоднорідне (навіть у випадках, коли розміри геологічних тіл з іншими теплофізичними властивостями досягають кількох сотень метрів), можуть виникати значні варіювання теплового потоку, які без знань про вплив контрастних включень та їх геометрії на розподіл теплового поля будуть некоректно роз'яснені. У зв'язку з цим виникає потреба в точних даних про розподіл температур i теплових потоків у неоднорідно побудованому геологічному середовищі. 


\section{Аналіз досліджень}

Різноманітність тектоно-магматичних процесів, нерівномірний розподіл джерел тепла, зміни механізму теплопередачі на різних глибинах значною мірою впливають на розподіл теплових потоків.

Істотні збурення теплового поля спричиняються термічними процесами в приповерхневому шарі, де зазвичай вимірюються теплові потоки. До них належать [1]:

- гідротермальні ефекти;

- топографія;

- накопичення осадків;

- ерозія;

- неоднорідність геологічного розрізу за теплофізичними властивостями.

Детальний розподіл температур і теплових потоків дозволяє:

- 3'ясувати питання походження та ролі локальних, регіональних і глобальних збурень теплового поля;

- звужувати множину конкуруючих фізико-геологічних моделей досліджуваного середовища;

- однозначно вирішувати поставлену геотермічну задачу.

Для побудови комплексної системи інтерпретації геотермічних даних необхідний ефективний числовий метод, який дозволить iз належною точністю оцінити вплив природних факторів на розподіл теплового поля, як кожного окремо, так і в усій сукупності їхньої дії в різні геологічні епохи.

Таким складним вимогам сучасної геотермії відповідає метод скінченних елементів (MCE).

Застосування MCE за математичного моделювання фізичних полів Землі має такі особливості [2;3]:

- досить точний опис складних криволінійних меж області визначення розв'язку;

- детальне розмежування середовища в зонах контакту і на межах;

- урахування реальних фізичних властивостей геологічного середовища і граничних умов будь-якого типу;
- можливість доступу до будь-якого елементу середовища у процесі математичного дослідження;

- оцінювання його впливу на структуру поля.

Чорноморська западина є наглядним прикладом ефективності застосування МСЕ для дослідження одночасного впливу структури Чорноморської западини, умов теплопередачі та генерації тепла в земній корі на розподіл температур і теплових потоків.

Основними тектонічними структурами Середземноморського рухомого поясу є Карпатська складчаста система, складчастобрилова споруда Гірського Криму та Чорноморська западина.

Чорноморська западина $є$ своєрідною тектонічною депресією, яка просторово збігається з глибоководною улоговиною Чорного моря.

Питання про механізм формування Чорноморської западини досить складне й дискусійне. ІІЇ вважають як новим, так і давнім утворенням, припускаючи при цьому різні механізми формування западини. В одних випадках перевагу віддають горизонтальним рухам, в інших - вертикальним [1].

Існує декілька гіпотез щодо походження та геологічного розвитку Чорноморської западини.

1. Причиною утворення западини може служити пластична течія речовини нижніх частин земної кори з зони западини до іiі периферії - магматичних ядер геосинклінальних підняттів [4].

2. Центральна частина западини - релікт давньої глибокої западини океанічного типу, яка ще не зазнала впливу процесів складчастості, інтрузивного магматизму та метаморфізму [5].

3. У докембрійську добу Чорноморська западина являла собою високоприпіднятий блок, на якому не відбувалося накопичення осадків. Подальше утворення «гранітного» шару стало неможливим через відсутність осадкового матеріалу [6]. 
Імовірно, що лише з часом можна дати більш однозначне пояснення походження Чорноморської западини.

Дані глибинного сейсмічного зондування свідчать, що потужність земної кори під Чорноморською западиною відносно континентальних районів, які їі ототочують, є порівняно невеликою 20-35 км.

У західній частині глибоководної улоговини моря кора особливо тонка (до 20 км).

Потужність базальту за цілковитої відсутності гранітного шару становить близько 5 км, осадкового шару - 16 км.

Максимальної товщини (до 30 км) кора досягає в східній частині глибоководної улоговини у міру наближення до Кавказу.

Потужність базальту збільшується до 15-17 км. Товщина осадкового шару зменшується до 8-10 км [7].

$\mathrm{y}$ центральних частинах Чорного моря гранітного шару немає, кора характеризується перехідним субконтинетальним типом будови.

Гранітний шар з'являється лише на периферіях западини, його потужність збільшується в напрямку до гірських споруд, що оточують іiі.

Крім сильного утоншення земної кори й відсутності гранітного шару для центральної частини Чорного моря характерна асейсмічність [7].

Складність будови Чорноморської западини підкреслюється наявністю дрібніших структурних елементів [7]:

- Західно-Чорноморської западини;

- Східно-Чорноморської западин;

- валом Андрусова;

- западини Сорокіна.

Теплове поле Чорноморської западини відрізняється значною диференціацією.

Підвищеними тепловими потоками (50-60 мВт/м²) характеризується ПівденноЗахідна частина Чорного моря (Болгарський сектор).

На південь від Криму виділяється субмеридіональна зона підвищених значень теплового потоку (50-65 мВт/м²). Ця аномальна зона просторово збігається з валом Андрусова і розділяє Чорноморську западину на два блоки з різною глибинною структурою.

На захід від Західнокавказького материкового схилу потоки змінюються від 50 до $60 \mathrm{мBT} / \mathrm{m}^{2}$, а в окремих місцях вимірювання їхня величина зростає до $80 \mathrm{MBT} / \mathrm{m}^{2}$.

Центральна улоговина Чорного моря характеризується низькими значеннями теплового потоку (12-20 мВт/м²) [1; 8; 9].

У разі занурення земної кори та відкладання осадкового шару виникають значні збурення теплового поля.

У Західно-Чорноморській западині зменшення теплового потоку становить близько $10 \mathrm{мBT} / \mathrm{m}^{2}$ на 1 км антропогенових осадків, а за потужності осадків 3 км потоки зменшуються в 2,5 рази.

У Східно-Чорноморській западині кореляції між потужністю осадків і тепловим потоком встановити не вдалося.

У Прикримській акваторії Чорного моря помітного впливу осадконакопичення на тепловий потік також не спостерігається [9].

Мета роботи - розроблення методики розрахунку температур і теплових потоків в акваторії Чорного моря на основі MCE.

\section{Постановка завдання}

Побудова теплової моделі Чорноморської западини органічно пов'язує окремі ланки єдиної системи досліджень:

- накопичення досвіду програмного забезпечення;

- практичне застосування обчислювального експерименту;

- пояснення закономірностей у розподіленні теплового поля;

- аналіз взаємозв'язку цих закономірностей з особливостями формування та геологічного розвитку Чорноморської западини;

- аналіз структури теплового балансу Землі;

- математичні судження про сили, які протистоять росту Всесвіту.

Географічне розташування досліджуваних профілів показано на рис. 1. 


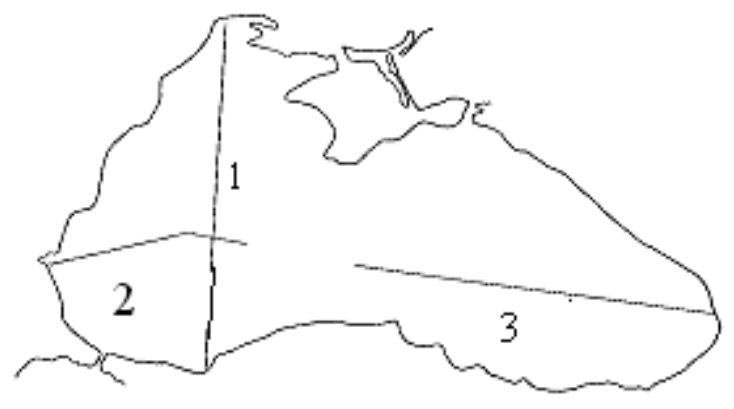

Рис. 1. Розташування профілів Чорноморської западини:

1 - профіль Одеса-Ерєглі;

2 - західна частина профілю Бургас-Сухумі;

3 - східна частина профілю Бургас-Сухумі

Скінченно-елементні аналоги профілю 1 Одеса-Ереглі показано на рис. 2, західна частина профілю 2 Бургас-Сухумі - на рис. 3, східна частина профілю 3 Бургас-Сухумі на рис. 4.

Величини теплопровідності $k$, генерації тепла $Q$ і теплового потоку $q$ наближені до реальних значень. Розміри всіх трьох моделей наведено в абсолютних одиницях.

Скінченно-елементна сітка для профілю Одеса-Ерегли містить 637 вузлів й 1152 елемента.

Західна частина профілю Бургас-Сухумі розбивається на 1008 елементів (кількість вузлів сітки 551), східна частина профілю Бургас-Сухумі - на 1054 елемента (кількість вузлів сітки 576).

Для вирішення поставленої задачі використовуємо лінійну апроксимацію пробної функції.

Розподіл температур у верхніх горизонтах Землі (до глибин 100 км) задовольняє стаціонарне рівняння теплопровідності [10; 11].

Для розрахунку температур і теплових потоків у земній корі використано скінченноелементний алгоритм, розроблений О. Зенкевичем і Д. Норрі [12; 13].

Визначальним рівнянням поширення тепла є рівняння Пуассона:

$$
k\left\{\frac{\partial^{2} \hat{T}}{\partial x^{2}}+\frac{\partial^{2} \hat{T}}{\partial y^{2}}\right\}+Q=0,
$$

де $k$ - коефіцієнт теплопровідності гірських порід;

$\hat{T}(x, y)$ - температура, що визначається всередині області $\Omega$;

$Q$ - джерело тепла.

На верхніх поверхнях геотермічних моделей $1,2,3$ (рис. $2,3,4$ ) Чорноморської западини задана гранична умова Діріхле:

$$
\hat{T}=8^{0} \mathrm{C} \text {. }
$$

Бічні стінки моделей $1,2,3$ ідеально ізольовані:

$$
k \frac{\partial \hat{T}}{\partial x}=0 .
$$

На нижніх межах моделей 1, 2, 3 задана гранична умова Неймана:

$$
k \frac{\partial \hat{T}}{\partial y}=q
$$

де $q$ - тепловий потік на одиницю довжини межі $S$.

\section{Скінченно-елементний алгоритм розв'язання двовимірного рівняння Пуассона}

Рівняння (1) та граничні умови (2)-(4) єдиним способом визначають задачу на множині $R$, що складається 3 області $\Omega$ i межі $S$ :

$$
R=\Omega+S .
$$

Якщо ввести систему лінійно незалежних базисних функцій

$$
\left\{N_{m} ; m=1,2,3, \ldots\right\},
$$

таких, що

$$
\left.N_{m}\right|_{S}=0
$$

для всіх $m$, то на області $\Omega$ можна запропонувати апроксимацію для температури $\hat{T}$ :

$$
\hat{T} \approx \sum_{m=1}^{M} a_{m} N_{m}
$$

де $a_{m}(m=1,2, \ldots, M)$ - параметри, які необхідно обчислити для одержання хорошого наближення [14]. 


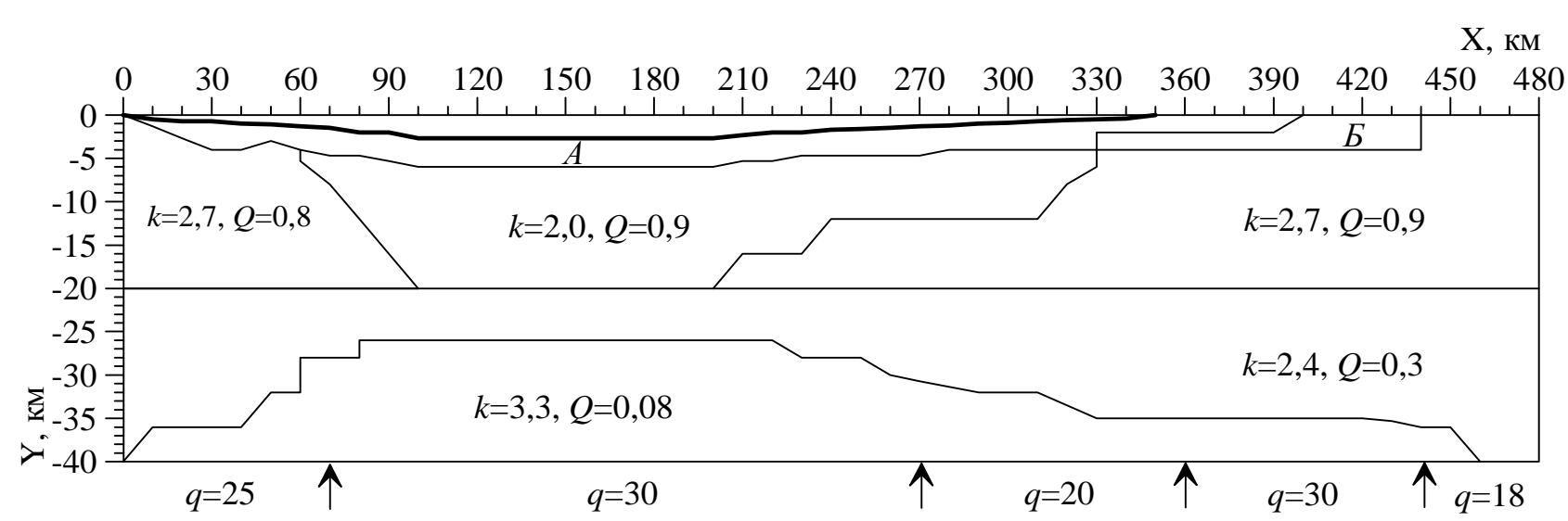

Рис. 2. Геотермічна модель 1 Чорноморської западини (профіль Одеса-Ерєглі):

$A-k=1,0, Q=1,0$;

L-k $=2,2, Q=1,2$

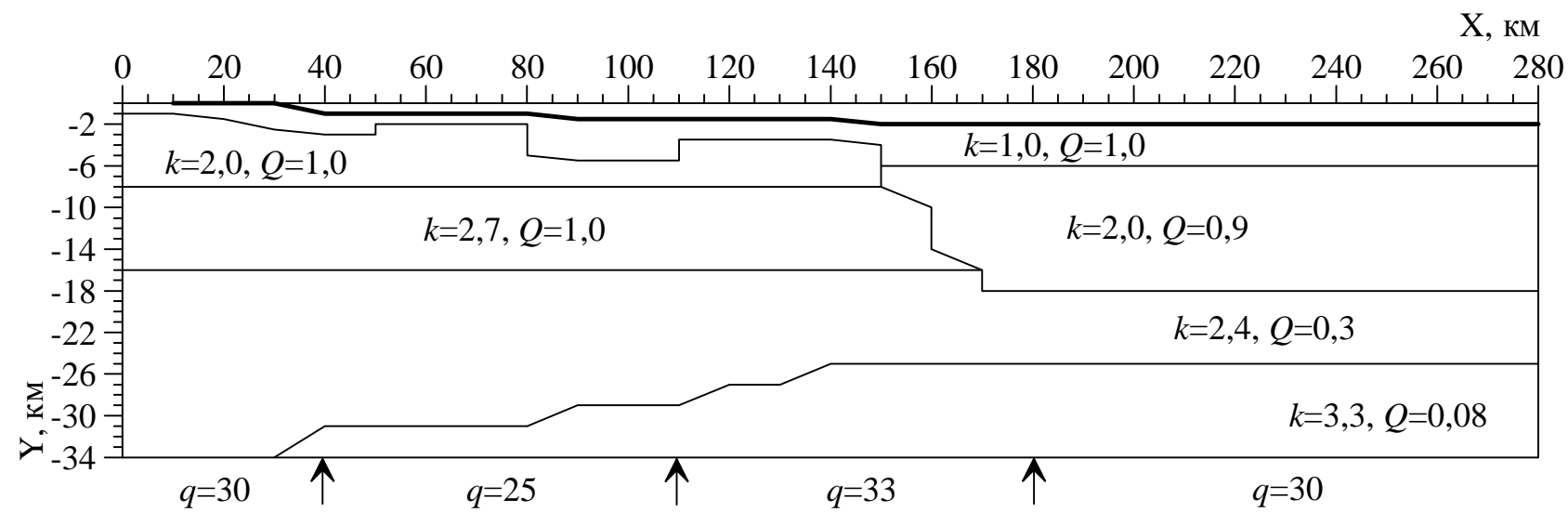

Рис. 3. Геотермічна модель 2 Чорноморської западини (західна частина профілю Бургас-Сухумі)

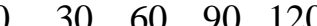

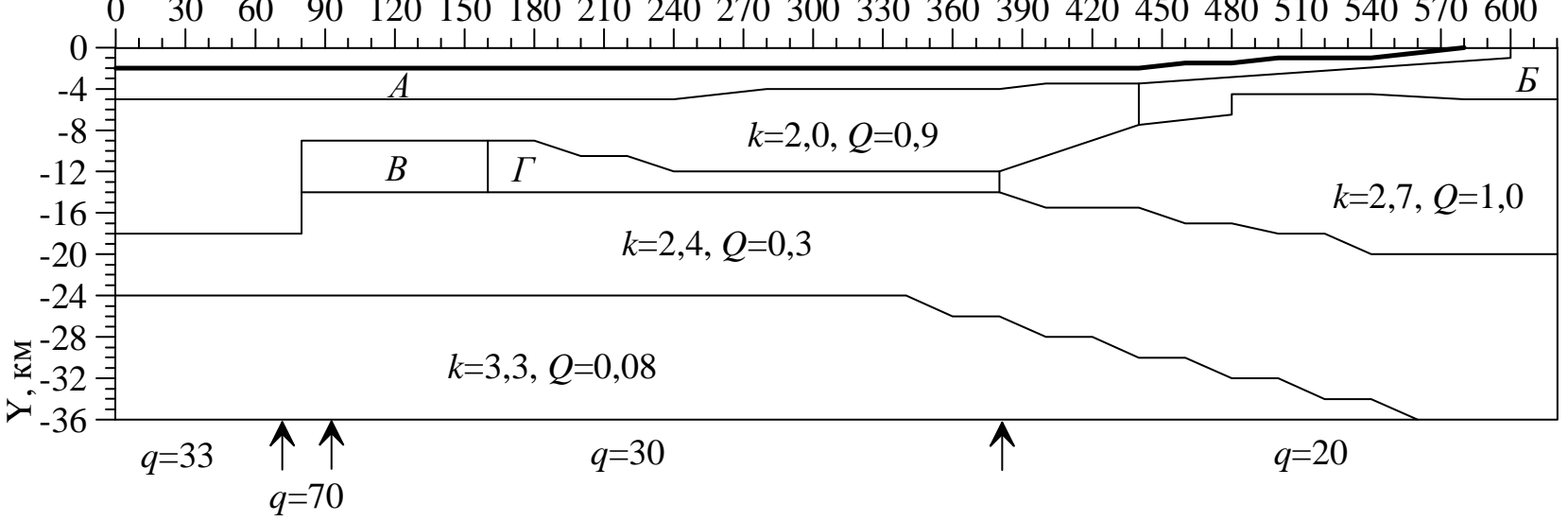

Рис. 4. Геотермічна модель 3 Чорноморської западини (східна частина профілю Бургас-Сухумі):

$A-k=1,0, Q=1,0$;

$5-k=2,0, Q=1,0$;

$B-k=2,7, Q=0,9$;

$\Gamma-k=2,4, Q=0,9$ 
Базисні функції цього типу іноді називають пробними функціями.

Iз варіаційного обчислення відомо, що розв'язок $\hat{T}(x, y)$, яке задовольняє рівняння (1)-(4), збігається 3 функцією, котра мінімізує функціонал

$$
\begin{aligned}
\Pi= & \iint_{\Omega}\left[\frac{1}{2} k\left\{\left(\frac{\partial T}{\partial x}\right)^{2}+\left(\frac{\partial T}{\partial y}\right)^{2}\right\}-Q T\right] d x d y+ \\
& +\int_{S} q T d S,
\end{aligned}
$$

де $T(x, y)$ - пробна функція, що належить класу допустимих функцій.

Для розглянутої задачі пробна функція $T(x, y)$ є допустимою, якщо вона неперервна й має кусково-неперервні перші похідні в $\Omega+S$ [13].

Необхідною умовою стаціонарності функціонала П $є$ повернення до нуля варіації $\delta \Pi$ :

$$
\begin{aligned}
& \delta \Pi=\int_{\Omega}\left[k\left\{\frac{\partial T}{\partial x} \delta\left(\frac{\partial T}{\partial x}\right)+\frac{\partial T}{\partial y} \delta\left(\frac{\partial T}{\partial y}\right)\right\}-Q \delta T\right] \times \\
& \times d \Omega+\int_{S} q \delta T d S=0 .
\end{aligned}
$$

Для перетворення рівняння (6) скористаємося формулою Гріна:

$$
\begin{aligned}
& \int_{\Omega}\left(\frac{\partial U}{\partial x} \frac{\partial V}{\partial x}+\frac{\partial U}{\partial y} \frac{\partial V}{\partial y}\right) d \Omega= \\
& =-\int_{\Omega} V\left(\frac{\partial^{2} U}{\partial x^{2}}+\frac{\partial^{2} U}{\partial y^{2}}\right) d \Omega+\int_{S} V\left(\frac{\partial U}{\partial x} n_{x}+\frac{\partial U}{\partial y} n_{y}\right) d S,
\end{aligned}
$$

де $n_{x}, n_{y}$ - компоненти одиничної зовнішньої нормалі до межі $S$.

Функції $U(x, y)$ та $V(x, y)$ неперервні в $\Omega+S$, їхні другі похідні кусковонеперервні $\Omega+S$.

Перші похідні функції $U(x, y)$ повинні бути неперервними, а для функції $V(x, y)$ вони можуть бути кусково-неперервними [13]. Розглянемо два випадки.

1. Функція $T(x, y)$ та iï перші похідні неперервні в облатсі $\Omega+S$.
Перетворимо інтеграл за допомогою формули Гріна:

$\int_{\Omega}\left[k\left\{\frac{\partial T}{\partial x} \frac{\partial}{\partial x}(\delta T)+\frac{\partial T}{\partial y} \frac{\partial}{\partial y}(\delta T)\right\}-Q \delta T\right] d \Omega=$

$=-\int_{\Omega} \delta T\left(k \nabla^{2} T-Q\right) d \Omega+\int_{S}\left(\frac{\partial T}{\partial x} n_{x}+\frac{\partial T}{\partial y} n_{y}\right) \delta T d S=$

$=-\int_{\Omega}\left(k \nabla^{2} T-Q\right) \delta T d \Omega+\int_{S}^{\partial T} \frac{\partial}{\partial n} \delta T d S$,

де

$$
\begin{aligned}
& \delta\left(\frac{\partial T}{\partial x}\right)=\frac{\partial}{\partial x}(\delta T) ; \\
& \delta\left(\frac{\partial T}{\partial y}\right)=\frac{\partial}{\partial y}(\delta T) ; \\
& \nabla^{2} T=\frac{\partial^{2} T}{\partial x^{2}}+\frac{\partial^{2} T}{\partial y^{2}} .
\end{aligned}
$$

Умови неперервності, що накладаються на $T(x, y)$, залишаються тими ж і для варіації $\delta T$. Підставляючи формулу (7) у рівняння (6), одержимо

$\delta \Pi=-\int_{\Omega}\left(k \nabla^{2} T-Q\right) \delta T d \Omega+\int_{S}\left(q+\frac{\partial T}{\partial n}\right) \delta T d S=0$.

Інтеграли в області й на межі в рівнянні (8) незалежні, отже:

$$
\begin{aligned}
& \int_{\Omega}\left(k \nabla^{2} T-Q\right) \delta T d \Omega=0 ; \\
& \int_{S}\left(q+\frac{\partial T}{\partial n}\right) \delta T d S=0 .
\end{aligned}
$$

3 урахуванням довільності варіації $\delta T$ в області $\Omega$ із рівняння (9) одержимо

$$
k \nabla^{2} T-Q=0 \text { в } \Omega,
$$

а $з$ формули (10):

$$
\frac{\partial T}{\partial n}+q=0 \text { на } S \text {. }
$$

2. Функція $T(x, y) \in$ неперервною й має кусково-неперервні перші похідні.

Поверхні розриву перших похідних розділяють область $\Omega$ на підобласті (елементи) $e$. До кожного елемента окремо можна застосувати формулу Гріна й отримати рівняння (7). 
Рівняння для області $\Omega$, отримане шляхом об'єднання рівнянь для підобластей, повинне збігатися з рівнянням (7) за винятком додаткового члена в правій частині - інтеграла на поверхні розділення.

Завдяки тому, що варіація $\delta T \epsilon$ довільною величиною на множині $R=\Omega+S$, інтеграл в області, поверхневий інтеграл та інтеграл на поверхні розділення в рівнянні (7) незалежні й окремо дорівнюють нулю.

Отже, рівняння (9)-(12) залишаються справедливими й тоді, коли функція $T(x, y)$ неперервна й має кусково-неперервні перші похідні [13].

Таким чином, проблема розриву похідних у разі переходу через межу між елементами вирішена.

3 викладеного випливає, що в інтегральному поданні розв'язок $T(x, y)$, що мінімізує функціонал, є ров'язком вихідного диференціального рівняння для поля

$$
k \nabla^{2} \hat{T}-Q=0 \text { в } \Omega,
$$

задовольняє умову Діріхле

$$
\hat{T}=8^{0} \text { на } S_{1}
$$

та умову Неймана

$$
\frac{\partial \hat{T}}{\partial n}+q=0 \text { на } S_{2},
$$

де $S=S_{1}+S_{2}$.

Процес дискретизації в МСЕ може бути розділений на два етапи:

- розбивка області $\Omega$ на ряд підобластей або елементів $\Omega^{e}$, що не перекриваються;

- нумерація вузлів і елементів.

Одним із центральних питань під час реалізації МСЕ для будь-якої задачі є вибір елемента.

Розподіл двовимірної області на трикутні елементи - найбільш оптимальний спосіб розбиття, оскільки за допомогою сім'ї трикутників можна легко й досить точно моделювати області 3 криволінійними межами складної форми.

Розміри елементів можуть бути змінними. Це дозволяє збільшити або подрібніти скінченно-елементну сітку на межах контакту середовищ із різними фізичними властивостями.
Побудова скінченно-елементної сітки - це свого роду мистецтво, що залежить від навичок дослідника. Некоректне розбиття області на елементи може призвести до хибних результатів, незважаючи на те, що при виконанні інших обчислювальних процедур була отримана висока точність.

Спосіб нумерації вузлів і елементів логічно простий, але в обчислювальному плані має велике значення.

Матриця $\mathbf{K}$ системи рівнянь, отримана у разі застосування скінченно-елементної апроксимації, матиме стрічкову розріджену форму.

Ширина стрічки матриці $\mathbf{K}$ визначається як число, на одиницю більше від різниці між номерами крайніх правого та лівого стовпців, що містять ненульові компоненти.

Отже, вузли та елементи повинні бути пронумеровані так, щоб забезпечити мінімум ширини стрічки, оскільки обчислювальна ефективність процесу розв'язання збільшується зі зменшенням ширини стрічки.

У загальному випадку для визначення півширини стрічки використовують співвідношення

$$
B_{S}=(d+1) m+1,
$$

де $B_{S}-$ півширина стрічки;

$d$ - максимальна різниця між меншим i найбільшим номерами вузлів будь-якого елемента в системі;

$m$ - кількість ступенів свободи в кожному вузлі.

Оптимальний спосіб нумерації вузлів i елементів у скінченно-елементній сітці визначається експериментально.

Метод скінченних елементів грунтується на ідеї апроксимації неперервної функції (у цьому випадку - температури) дискретною моделлю, що будується на множині кусковонеперервних функцій, визначених на скінченному числі підобластей (елементів).

Якщо базисні функції визначено кусковим образом, то стає очевидною рівність нулю базисної функції всюди, крім розглянутого елемента й підобластей, які безпосередньо примикають до нього. 
Це дозволить одержати апроксимуючі рівняння зі стрічковими матрицями, які забезпечують МСЕ велику перевагу.

Розіб'ємо область, показану на рис. 5, на $m$ скінченних трикутних елементів.

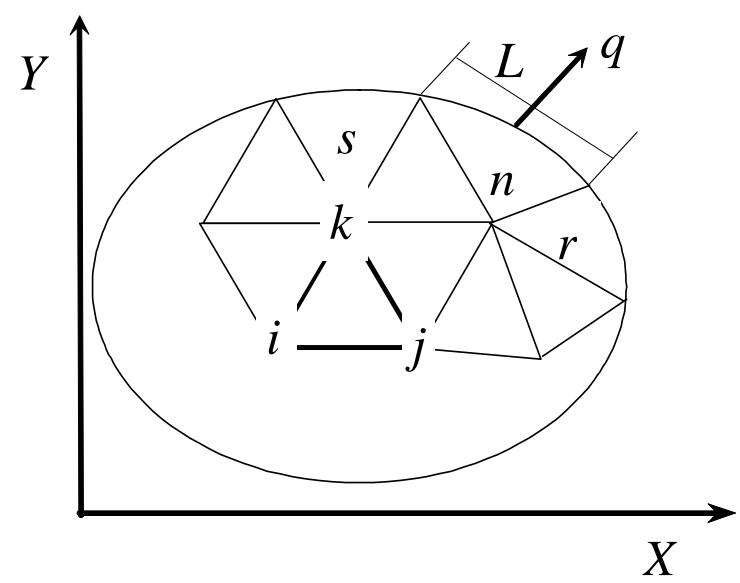

Рис. 5. Скінченно-елементна сітка всередині двовимірної області, яка використовує трикутні елементи

Номери вузлів $i, j, k$ зазначені в порядку, що відповідає руху проти годинникової стрілки.

Функціонал $\Pi^{e_{m}}$ у межах кожного елемента дорівнює

$$
\Pi^{e_{m}}=\iint_{e_{m}}\left[\frac{1}{2} k\left\{\left(\frac{\partial T}{\partial x}\right)^{2}+\left(\frac{\partial T}{\partial y}\right)^{2}\right\}-Q T\right] d x d y .
$$

Функціонал П в області $\Omega$ визначається сукупністю інтегральних функціоналів:

$$
\Pi=\sum_{m=1} \Pi^{e_{m}} .
$$

Поверхневий інтеграл у рівнянні (13) розглянемо окремо.

Як базисна функція найчастіше застосовується лінійний поліном із трьома коефіцієнтами:

$$
N_{i}^{e}=a_{i}^{e}+b_{i}^{e} x+c_{i}^{e} y .
$$

Базисна функція $N_{i}^{e}\left(x_{i}, y_{i}\right)$ приймає значення одиниця у вузлі $i$ та дорівнює нулю у вузлах $j, k$ :

$$
N_{i}^{e}\left(x_{i}, y_{i}\right)=1 \text {; }
$$

$$
N_{i}^{e}\left(x_{j}, y_{j}\right)=N_{i}^{e}\left(x_{k}, y_{k}\right)=0 .
$$

Умови (14) приводять до такої системи рівнянь

$$
\left[\begin{array}{lll}
1 & x_{i} & y_{i} \\
1 & x_{j} & y_{j} \\
1 & x_{k} & y_{k}
\end{array}\right]\left[\begin{array}{c}
a_{i}^{e} \\
b_{i}^{e} \\
c_{i}^{e}
\end{array}\right]=\left[\begin{array}{l}
1 \\
0 \\
0
\end{array}\right]
$$

з розв'язками:

$$
\begin{aligned}
& a_{i}^{e}=\frac{x_{j} y_{k}-x_{k} y_{j}}{2 \Delta^{e}} ; \\
& b_{i}^{e}=\frac{y_{j}-y_{k}}{2 \Delta^{e}} ; \\
& c_{i}^{e}=\frac{x_{k}-x_{j}}{2 \Delta^{e}},
\end{aligned}
$$

де $\Delta^{e}$ - площа трикутника.

Постійні $a_{j}, a_{k}, b_{j}, b_{k}, c_{j}, c_{k}$ можна визначити циклічною перестановкою індексів.

Глобальна базисна функція $T(x, y)$ неперервна під час переходу через границі елемента й може виражатися через значення температури у вузлах елемента й базисної функції елемента $N^{e}$ :

$$
T(x, y)=N_{i} T_{i}+N_{j} T_{j}+N_{k} T_{k}=\mathbf{N}^{e} \mathbf{T}^{e}
$$

де

$$
\begin{aligned}
& \mathbf{N}^{e}=\left[N_{i}, N_{j}, N_{k}\right] ; \\
& \mathbf{T}^{e}=\left[\begin{array}{c}
T_{i} \\
T_{j} \\
T_{k}
\end{array}\right]
\end{aligned}
$$

являє собою вектор вузлових значень.

Для мінімізації функціонала П необхідно спочатку оцінити внесок елемента $e$ в кожну похідну, наприклад $\frac{\partial \Pi}{\partial T_{i}}$, а потім скласти всі отримані величини й прирівняти їх до нуля.

Такий внесок у $\frac{\partial \Pi}{\partial T_{i}}$ будуть давати тільки ті елементи, які належать вузлу $i$.

Диференціюючи рівняння (13) і використовуючи розкладання (15), одержимо: 


$$
\begin{aligned}
& \quad \frac{\partial \Pi^{e}}{\partial T_{i}}=\frac{1}{4 \Delta^{2}} \iint\left[k\left\{\left[b_{i}, b_{j}, b_{k}\right]\{T\}^{e} b_{i}+\right\}\right. \\
& \left.\left.+\left[c_{i}, c_{j}, c_{k}\right]\{T\}^{e} c_{i}\right]\right\} d x d y- \\
& -\frac{1}{2 \Delta} \iint Q\left(a_{i}+b_{i} x+c_{i} y\right) d x d y .
\end{aligned}
$$

Кожний елемент дає внесок тільки в три похідні, пов'язані з його вузлами:

$$
\left\{\frac{\partial \Pi}{\partial T}\right\}^{e}=\left\{\begin{array}{l}
\frac{\partial \Pi^{e}}{\partial T_{i}} \\
\frac{\partial \Pi^{e}}{\partial T_{j}} \\
\frac{\partial \Pi^{e}}{\partial T_{k}}
\end{array}\right\} .
$$

Рівняння (16) і два інших подібних можна записати у вигляді

$$
\left\{\frac{\partial \Pi}{\partial T}\right\}^{e}=[h]\{T\}^{e}+\{F\}^{e} .
$$

Вираз (17) можна отримати для кожного елемента.

Матриця $[h]$ визначається так. Припустимо, що теплопровідність $k$ - величина постійна всередині елемента. Площа елемента дорівнює

$$
\iint d x d y=\Delta .
$$

Проводячи інтегрування в рівнянні (16), одержимо

$$
[h]=\frac{k}{4 \Delta}\left\{\left[\begin{array}{lll}
b_{i} b_{i} & b_{j} b_{i} & b_{k} b_{i} \\
b_{i} b_{j} & b_{j} b_{j} & b_{k} b_{j} \\
b_{i} b_{k} & b_{j} b_{k} & b_{k} b_{k}
\end{array}\right]+\left[\begin{array}{lll}
c_{i} c_{i} & c_{j} c_{i} & c_{k} c_{i} \\
c_{i} c_{j} & c_{j} c_{j} & c_{k} c_{j} \\
c_{i} c_{k} & c_{j} c_{k} & c_{k} c_{k}
\end{array}\right]\right\} .
$$

Відзначимо, що матриця твердості елемента $[h]$ симетрична.

Позначимо через $\{F\}^{e}$ другий член у правій частині виразу (16). Якщо прийняти, що величина $Q$ не змінюється всередині елемента, то інтегруючи

$$
F_{i}=-\frac{Q}{2 \Delta} \iint\left(a_{i}+b_{i} x+c_{i} y\right) d x d y,
$$

одержуємо остаточний результат

$$
\{F\}^{e}=-\frac{Q \Delta}{3}\left\{\begin{array}{l}
1 \\
1 \\
1
\end{array}\right\} \text {. }
$$

Фізичний параметр елемента - генерація тепла - розглядається як внутрішнє розподілене навантаження елемента.

Поєднуючи всі похідні функціонала П й прирівнюючи їх до нуля, одержимо остаточні рівняння процесу мінімізації:

$$
\frac{\partial \Pi}{\partial T_{i}}=\sum \frac{\partial \Pi^{e}}{\partial T_{i}}=0
$$

За допомогою рівняння (17) вираз (18) можна записати

$$
\frac{\partial \Pi}{\partial T_{i}}=\sum \sum h_{i k} T_{k}+\sum F_{i},
$$

де підсумовування здійснюється по всіх елементах і вузлах.

Таким чином, рівняння теплопровідності (1) за МСE перетворилося на рівняння

$\mathbf{K T}+\mathbf{F}=0$,

де $\mathrm{K}=\sum \sum h_{i k}-$ загальна матриця твердості системи;

$$
\mathrm{F}=\sum F_{i}-\text { внутрішнє навантаження. }
$$

Процедура введення умов Діріхле в матричне рівняння системи полягає в такому. Якщо $p$ - вузол, в якому значення температури задається явно $\left(T_{p}=t_{p}\right.$ в загальному випадку), то $p$-й рядок матриці $R=-F$ заміняється заданим значенням $t, k_{p p}-$ одиницею, а інші елементи $p$-го рядка й $p$-го стовпця - нулями. Потім 3 інших $R$ треба відняти $k_{i p} t_{p}$, тобто

$$
\left[\begin{array}{cccc}
1 & 0 & 0 & 0 \\
0 & k_{22} & k_{23} & 0 \\
0 & k_{32} & k_{33} & 0 \\
0 & 0 & 0 & 1
\end{array}\right]\left[\begin{array}{l}
T_{1} \\
T_{2} \\
T_{3} \\
T_{4}
\end{array}\right]=\left[\begin{array}{c}
t_{1} \\
R_{2}-k_{21} t_{1}-k_{24} t_{4} \\
R_{3}-k_{31} t_{1}-k_{34} t_{4} \\
t_{4}
\end{array}\right] .
$$

Такий метод урахування головних граничних умов зберігає симетрію матриці $\mathbf{K}$.

Для обліку граничних умов (3) не потрібно вживати яких-небудь спеціальних заходів, оскільки мінімізація в цих граничних точках $€$ достатньою для виконання граничних умов Неймана як природний наслідок. 
Для визначення граничних умов (4) функціонал (5) береться по межі, що задовольняє умову (4). Такий диференціал існує тільки для елементів, які утворюють межу, наприклад, елементи $s, n, r$ (рис. 5).

Розглянемо поверхню елемента $r-s$. Якщо потік $q$ приймає постійне значення вздовж поверхні й температура $T$ лінійно міняється від $T_{r}$ до $T_{s}$, то

$\frac{\partial}{\partial T_{r}}\left\{\int q T d S\right\}^{e}=\frac{1}{2} q \sqrt{\left(x_{r}-x_{s}\right)^{2}+\left(y_{r}-y_{s}\right)^{2}}=\frac{1}{2} q L$.

Якщо розглядається $\frac{\partial \Pi}{\partial T_{r}}$ або «рівновага» вузла $r$, необхідно додати подібні члени від двох сусідніх елементів. Тобто величина $q$ позначає розподілене зовнішнє навантаження на одиницю довжини межі.

У геотермічних завданнях шуканою величиною $\epsilon$ не тільки температура, але й тепловий потік. Тепловий потік у вертикальному й горизонтальному напрямках для кожного вузла скінченно-елементної розбивки можна знайти з рівняння (5):

$q=-k\{\operatorname{grad} T\}=-\left\{\begin{array}{l}\frac{\partial T}{\partial x} \\ \frac{\partial T}{\partial y}\end{array}\right\}=-\frac{k}{2 \Delta}\left\{\begin{array}{l}b_{i} b_{j} b_{k} \\ c_{i} c_{j} c_{k}\end{array}\right\}\left\{\begin{array}{c}T_{i} \\ T_{j} \\ T_{k}\end{array}\right\}$.

\section{Геоенергетичний баланс Землі}

У всіх сучасних тектонічних гіпотезах внутрішнє тепло Землі розглядається як основна рушійна сила тектогенеза.

За одними гіпотезами Земля є своєрідною «тепловою машиною». Внутрішнє тепло Землі - це єдине та визначальне джерело енергії у всіх глибинних процесах.

Відповідно до інших гіпотез теплова енергія Землі разом із фізико-хімічними процесами в надрах поєднується 3 зовнішніми силами, що виникають під дією космічних факторів.
Результати геофізичних досліджень дають можливість зробити кілька припущень щодо природи додаткового теплопотока в тектонічно активних районах.

Найбільш імовірними джерелами тепла у верхній мантії $є$ неоднорідності будови, масоперенос, хімічні реакції, приливне тертя. Слід розрізняти первинну природу неоднорідностей і вторинні неоднорідності [8].

Передбачається, що первинні неоднорідності могли зберегтися 3 часу утворення Землі або виникнути в процесі іiі раннього розвитку. Якщо це так, то 3 неоднорідностями, які мають первинну природу, слід пов'язувати підвищену концентрацію радіоактивних елементів. Однак теплові аномалії тектонічно активних зон нетривалі в геологічних масштабах часу, тому вони не можуть бути обумовлені радіогенним теплом. Крім того, у цих зонах підвищеною радіоактивністю не відрізняються ні осадкові, ні вивержені породи [8].

Перетворення речовини, викликане зміною термодинамічних умов, може бути причиною вторинних неоднорідностей верхньої мантії.

Перебудова речовини у верхній мантії Землі супроводжується зміною фізичних властивостей й об' ємом речовини, виділенням або поглинанням тепла. Кількість виді-

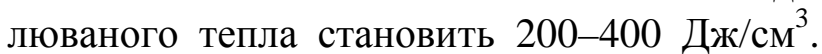
Це на порядок менше, ніж потрібно для одержання спостережених високих теплових потоків у тектонічно активних районах.

Таким чином, 3 енергетичного погляду, процеси перебудови речовини не можуть впливати на формування теплового режиму верхньої мантії й розвиток тектономагматичних процесів. Однак перебудови речовини приводять до утворення більше щільних або легких фаз, що викликає порушення механічної рівноваги в мантії Землі [8].

Більш прийнятним джерелом тепла слід вважати винесення тепла 3 більших глибин унаслідок перерозподілу енергії й речовини в надрах Землі [8]. 
Природа сил, які приводять до тектонічної активізації Землі, дотепер залишається гіпотетичною.

Сучасні дослідження показують, що фізико-геологічні й геохімічні процеси нездатні створювати в літосфері латеральні неоднорідності. Більше того, ці процеси можуть виникати тільки як реакції на вплив сили неземного походження.

Відповідно до Нової ротаційної гіпотези структуроутворення знайдено реальне джерело, під впливом якого відбувається тектонічна активізація Землі. Це джерело - обертання Землі, точніше варіації іiі ротаційного режиму. Ротаційні сили зумовлені взаємодією нашої планети 3 навколишніми іiі космічними полями [15].

У 1965 р. виявлено, що з космосу до Землі у всіх напрямках ідуть слабкі радіосигнали, які спостерігалися при довжині хвилі 7,35 см. Відповідно до висунутої гіпотези випромінювання обумовлено залишковими процесами, які відбувалися ще в дуже гарячому Всесвіті. Теоретичне припущення про можливості існування такого випромінювання зроблено набагато раніше [16].

Якщо повернутися назад у часі, то густина речовини й енергія зростають. У такому гарячому Всесвіті фотони народжуються й зникають, перетворюючись у пари електронпозитрон.

Між усіма частинками існує теплова рівновага. Чим старший Всесвіт, тим більшою стає довжина хвилі випромінювання.

Зі збільшенням довжини хвилі енергія фотонів і температура всієї нагрітої суміші зменшується. Цей ефект можна спостерігати й зараз - квазари, галактики і їхні скупчення посилають випромінювання, довжини хвиль якого зрушені в довгохвильову область порівняно 3 тими ж лініями в спектрі тих же елементів на планеті Земля. Звідси випливає, що далекі об' єкти віддаляються від нас [16; 17].

Весь Всесвіт заповнений фотонним газом зі планковським спектром. Фотони несуть із собою інформацію про дуже давню історію Всесвіту і $\epsilon$ найбільш яскравим доказом ii розширення.
Розбігання галактик відбувається не тільки відносно Землі. Сутність розширення Всесвіту полягає в тому, що з будь-якої точки Всесвіту галактики будуть видні як далекі галактики, які віддаляються від цієї точки.

Зараз у науковому світі не залишається сумнівів у тому, що космічний фон мікрохвильового реліктового випромінювання $є$ залишком тих фотонів, які зіграли свою роль у процесі еволюції Всесвіту [16; 17].

Нині існує реліктове випромінювання фотонів порівняно молодого походження. Вік молодого «реліктового» випромінювання становить 12 років. Ці «молоді» фотони мають парадоксальні властивості:

- незалежно від термодинамічної ситуації фотони не скидають свою енергію, швидше, навпаки, інтенсивно іiі акумулюють;

- здатні накопичувати величезну кількість енергії, достатньої для компенсації гравітаційної тяги чорної діри;

- на відміну від стохастичних систем молодий фотонний газ «не губить» пам'яті, «знає» своє майбутнє, тому що має достатню кількість енергії для збереження інформації та передачі їі на величезні відстані;

- діють як складно влаштовані осцилятори;

- перебувають у гармонічній злагоді зі старшим «поколінням» фотонів навколоземного простору;

- мають шестилітню циклічність (майже зникнувши, миттєво накопичують енергію 3 більшим запасом міцності).

До джерел, що живлять Всесвіт (ядерний синтез, чорні діри, флуктуації вакууму), необхідно віднести також і молоде «покоління» дивних фотонів, здатне протистояти росту Всесвіту.

У молодому фотонному газі можна знайти високошвидкісні фотони, які стрімко накопичують енергію та стрімко її скидають. Тому в спектрі випромінювання своєрідна асиметрія зумовлена «марнотратним» поводженням «молоді» та принципом зростання ентропії. 
За роботу в якій-небудь системі необхідно заплатити не тільки енергією, але й зростанням ентропії системи. Енергію можна повернути, якщо віддати отриману роботу назад.

Зменшити зростаючу ентропію не можна, оскільки в оберненому циклі вона зростає ще більше. Крім того, треба платити ентропією не тільки за роботу, але й за вимір фізичних величин.

Нерівність у законі ентропії означає, що легко втратити енергію, нічого не одержавши натомість, але не можна їі заробити, нічого за це не заплативши [16].

У фізичних науках нерідко бувають випадки, коли необхідно відволіктися від звичних рамок класичної фізики й створити нову гіпотезу. Такою гіпотезою виявилася гіпотеза німецького фізика Планка про те, що електромагнітне випромінювання випускається у вигляді окремих порцій енергій - квантів, величина яких пропорційна частоті випромінювання:

$$
\varepsilon=h \vee,
$$

де $h$ - постійна Планка.

Припущення Планка дало вичерпний опис рівноважного теплового випромінювання й усунуло суперечність закону Релея-Джинса, яка залишилася в історії за назвою «ультрафіолетова катастрофа».

Закон Релея-Джинса призводить до загального нескінченного випромінювання, що зовсім суперечить досвіду [18].

Відкриття Планка знайшло фізичний зміст, коли через п'ять років Ейнштейн прийшов до висновку, що, якщо квант має енергію, то він має право на самостійне існування як частинка, яка рухається зі швидкістю світла 3 енергією $\varepsilon$ й масою спокою, що дорівнює нулю.

Фотон повинен бути складним світом. Справедливо й те, що цей світ замкнутий, або, принаймні, майже замкнутий. Фотон надійно захищений від зовнішніх впливів, і його ясно обкреслені функції охороняються «суворими митницями».
Завдяки своїм унікальним властивостям фотон є індивідуумом.

Відсутність маси спокою не заважає фотону випробовувати вплив гравітаційного поля, оскільки він має енергію й імпульс. Отже, необхідно враховувати рух Землі щодо реліктового випромінювання й молодого фотонного випромінювання.

Теорія рівномірного розподілу пояснила стільки фактів, що вона повинна містити частку істини. Однак теорія вірна не повністю, тому що не може пояснити всіх явищ. Її не можна ні відкинути, ні зберегти незмінною [18].

Нові факти, які відкриваються сьогодні вченим, настільки дивні й парадоксальні, що не всі дослідники їх приймають.

За сучасного стану науки й екологічних проблемах Землі необхідно не тільки відзначати ці факти, але й знаходити зв'язки між ними.

\section{Аналіз отриманих результатів}

Як видно з рис. 6, 7, 8, у зонах контакту двох середовищ із різною теплопровідністю спостерігається стрибкоподібна зміна теплового потоку. Будь-яка аномалія містить у собі певну інформацію.

Специфічна форма аномалій на бортах западини свідчить про те, що контактні зони 3 контрастною теплопровідністю виходять на поверхню Землі. Зміна значення радіогенної генерації тепла не викликає різких стрибків у розподілі теплового потоку. Аномалії мають більше згладжену форму. Очевидно, що збільшення глибинного теплового потоку відбивається в амплітуді аномалій теплового поля.

\section{Висновки}

Побудовано фізико-геологічну й математичну моделі Чорноморської западини. Аналіз теплового поля грунтується на розв'язку стаціонарного рівняння теплопровідності зі змінними граничними умовами. 


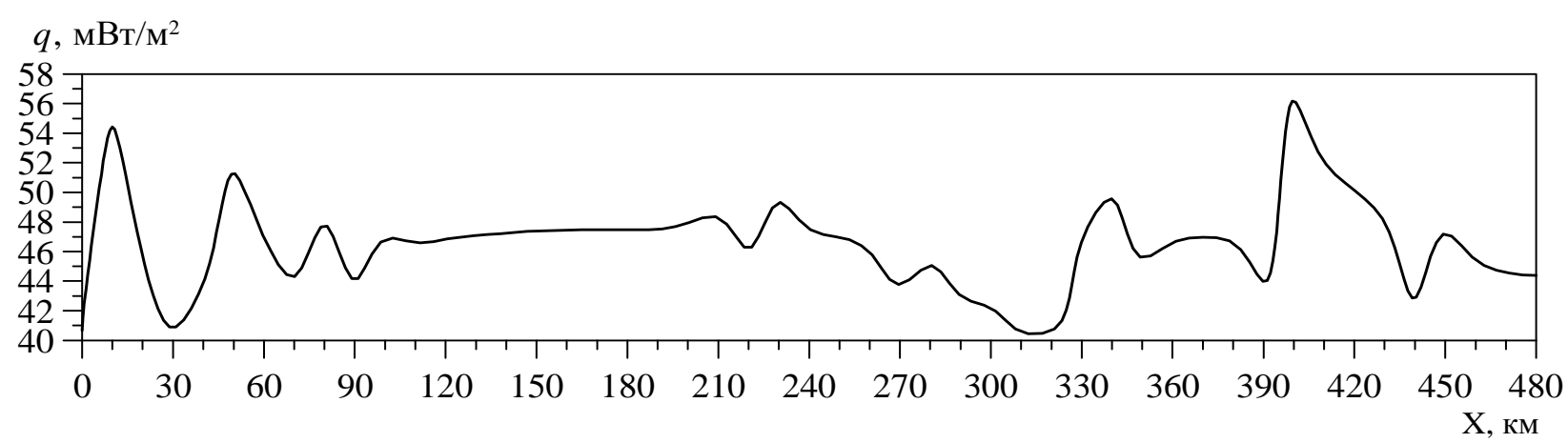

$a$

$\mathrm{X}, \mathrm{Км}$

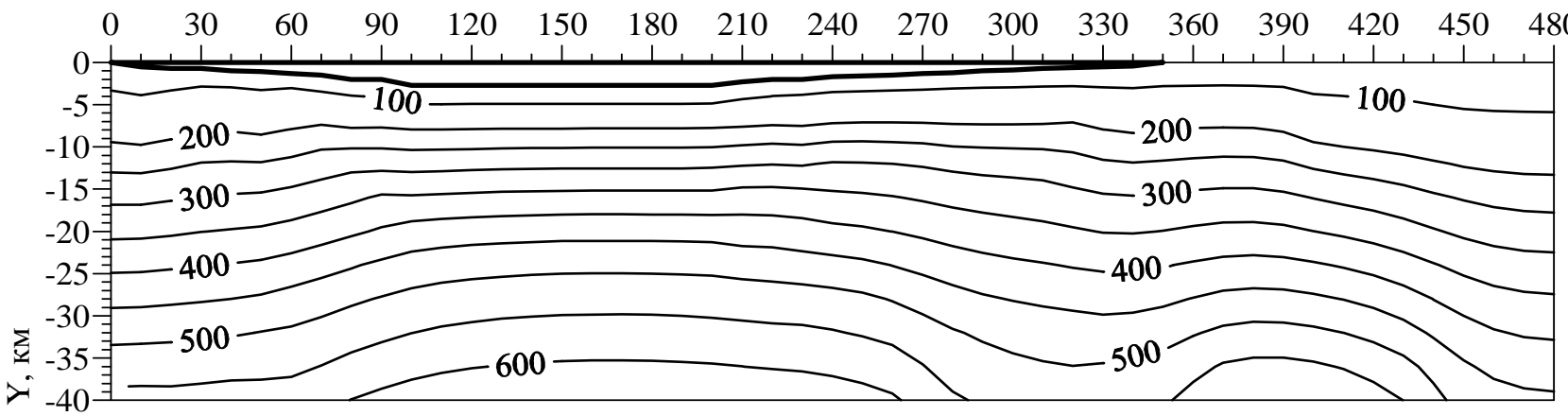

$\sigma$

Рис. 6. Теплова модель Чорноморської западини (профіль Одеса-Ерєглі): $a$ - розподіл поверхневого теплового потоку; б - розподіл температури

\section{$q, \mathrm{MBT} / \mathrm{M}^{2}$}

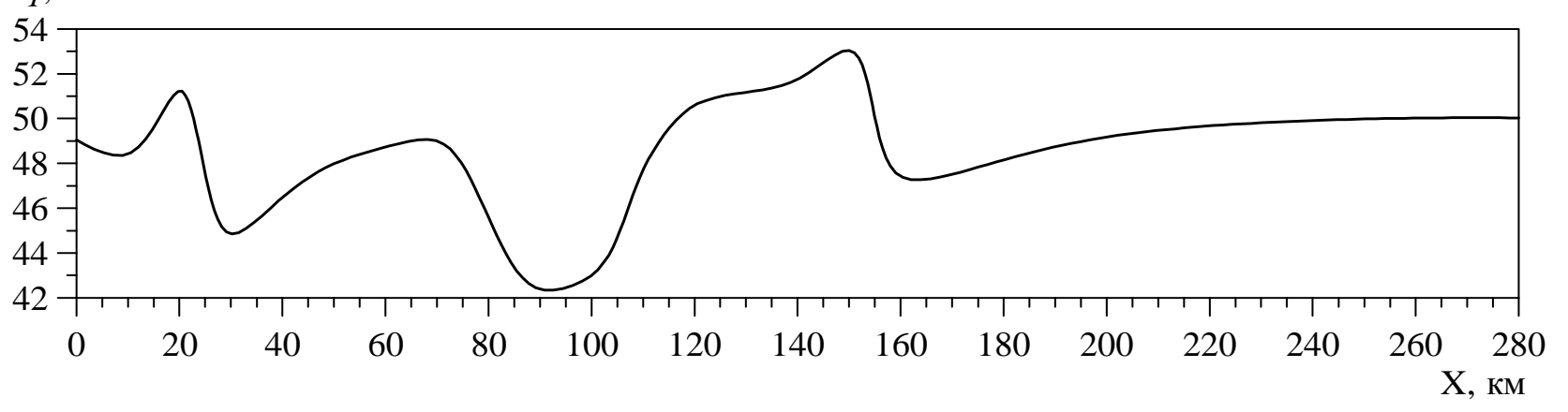

$a$

$\mathrm{X}$, км

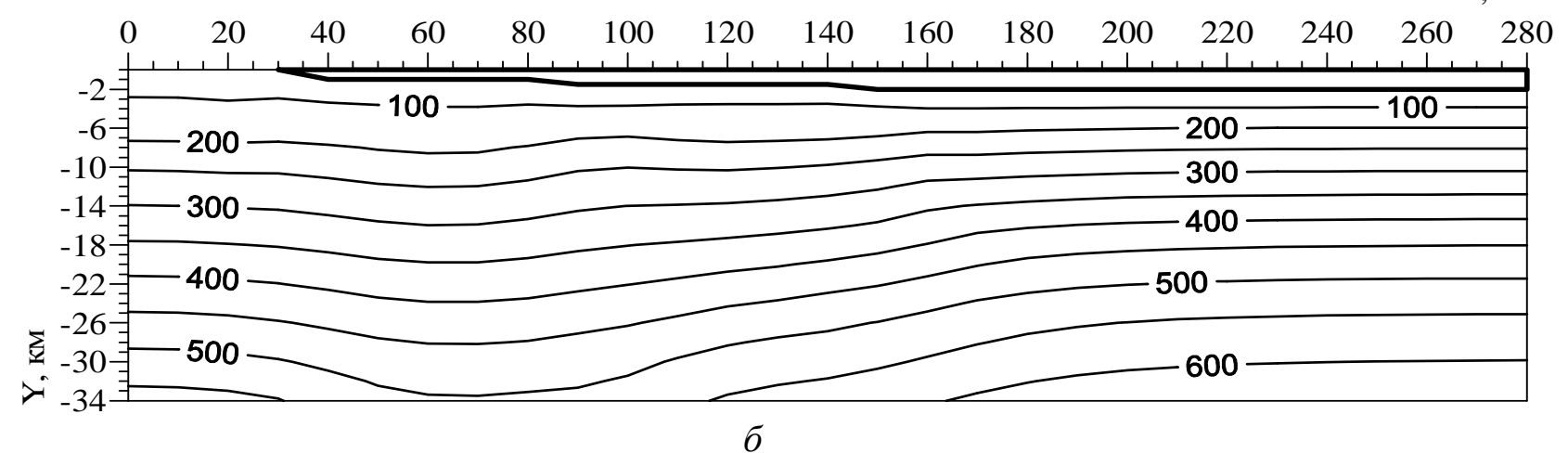

Рис. 7. Теплова модель Чорноморської западини (західна частина профілю Бургас-Сухумі): $a$ - розподіл поверхневого теплового потоку; $\sigma$ - розподіл температурі 


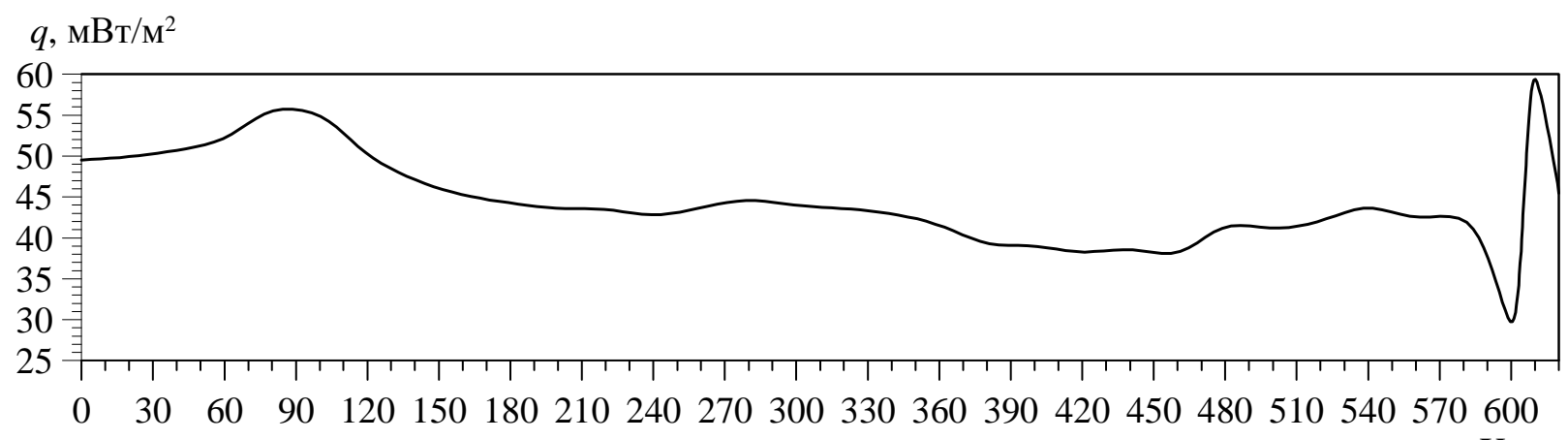

$a$

$\mathrm{X}$, км

$0 \quad 30 \quad 60 \quad 90 \quad 120150180210240270300330360390420450480510540570600$

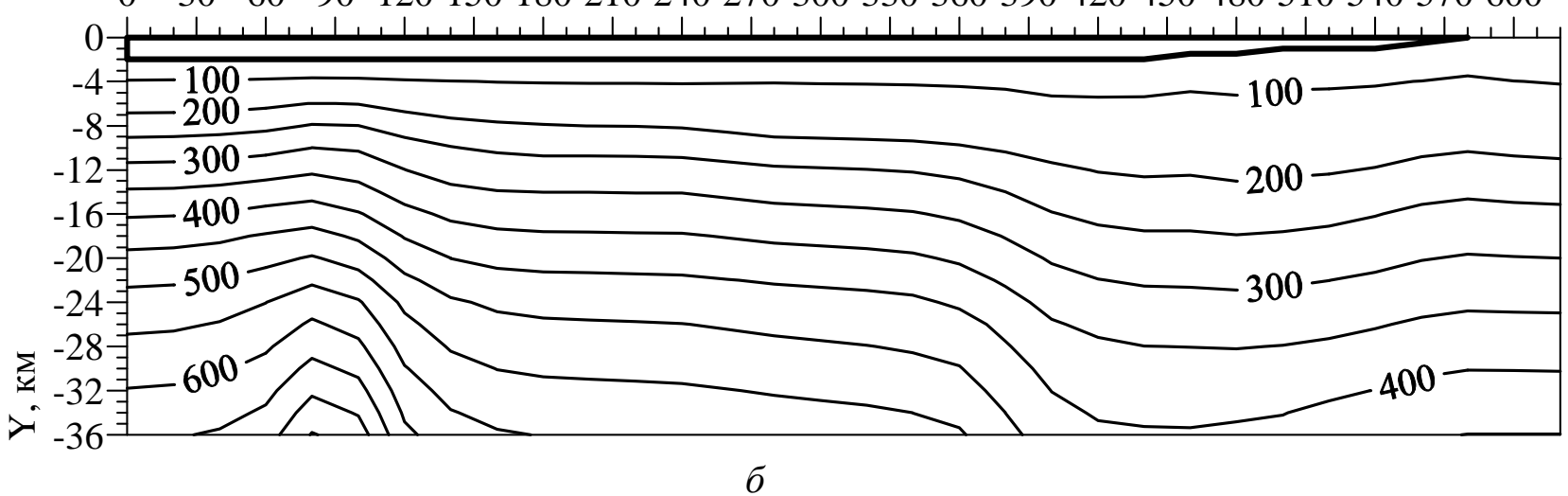

Рис. 8. Теплова модель Чорноморської западини (східна частина профілю Бургас-Сухумі): $a$ - розподіл поверхневого теплового потоку; $\sigma$ - розподіл температурі

Для одержання високоточних результатів використовували обчислювальний експеримент, за допомогою якого створювали необхідні комбінації природних факторів і геотермічних параметрів. Розглянуто перекручування теплового поля стаціонарної природи, а саме рельєф, структурно-геологічні неоднорідності, контрастну теплопровідність, нерівномірне розподіл джерел тепла.

Точність розв' язку двовимірного рівняння Пуассона становить не більше $0,6 \%$.

\section{Література}

1. Кутас Р.И. Моделирование теплового поля континентальной литосферы / Р.И. Кутас, В.А. Цвященко, И.Н. Корчагин. - К.: Наук. думка, 1989. - 191 с.
2. Кутас Р.И. Исследование вариаций теплового потока в зонах с контрастной теплопроводностью / Р.И. Кутас, Н.И. Бахова // Доп. НАН України. - 1995. - № 4. - С. 75-77.

3. Бахова H.I. Термопружні напруження в неоднорідних геологічних середовищах складного обрису / Н.I. Бахова // Вісник НАУ. - 2010. - № 1. - С. 70-77.

4. Муратов М.B. Строение складчатого основания Средиземноморского пояса Европы и Западной Азии и главнейшие этапы развития этого пояса / М.В. Муратов // Геотектоника. - 1969. - № 2. - С. 3-21.

\section{5. Милановский E.E. Геологическое} строение Кавказа / Е.Е. Милановский, В.Е. Хаин. - М.: МГУ, 1963. - 230 с. 
6. Сологуб В.Б. Литосфера Украины / В.Б. Сологуб. - К.: Наук. думка, 1986. $184 \mathrm{c}$.

7. Чекунов А.В. Геологическое строение и история развития Причерноморского прогиба / А.В. Чекунов, А.А. Веселов, А.И.Гилькман. - К.: Наук. думка, 1976. $161 \mathrm{c}$.

8. Кутас Р.И. Поле тепловых потоков и термическая модель земной коры / Р.И. Кутас. - К.: Наук. думка, 1978. - 147 с.

9. Кутас Р.И. Геотермический режим и сейсмичность Крымского региона / Р.И. Кутас, В.А. Цвященко / Геотермия сейсмичных и асейсмичных зон. - М.: Наука, 1993. С. 15-27.

10. Магницкий В.A. Внутреннее строение и физика Земли / В.А. Магницкий. - М.: Недра, 1965. - 380 с.

11. Любимова E.A. Термика Земли и Луны / Е.А. Любимова - М.: Наука, 1968. - 280 с.
12. Зенкевич $O$. Метод конечных элементов в технике / О. Зенкевич. - М.: Мир, 1975. - 541 с.

13. Норри Д. Введение в метод конечных элементов / Д. Норри, Ж. Фриз. - М.: Мир, 1981. - 304 c.

14. Зенкевич O. Конечные элементы и аппроксимация / О. Зенкевич, К. Морган. - М.: Мир, 1986. - $318 \mathrm{c}$.

15. Тяпкин К.Ф. Новая ротационная гипотеза структурообразования и еe геологоматематическое обоснование / К.Ф. Тяпкин, М.М. Довбнич. - Донецк: Ноулидж, 2009. 342 c.

16. Смородинский Я.А. Температура / Я.А. Смородинский. - М.: Наука, 1987. - 191 с.

17. Савельєв И.В. Курс общей физики. Т. 3 / И.В. Савельев. - М.: Наука, 1987. - 317 с.

18. Пуанкаре А. О науке / А. Пуанкаре. М.: Наука, 1990. - С. 735.

Стаття надійшла до редакції 04.11.10. 